$631.411(282.256 .341)$

DOI: $10.18101 / 2542-0623-2020-2-37-54$

\title{
ЭКОЛОГО-ГЕОГРАФИЧЕСКИЕ ЗАКОНОМЕРНОСТИ РАСПРЕДЕЛЕНИЯ ПОЧВ И ПОЧВЕННЫЕ РЕСУРСЫ ЦЕНТРАЛЬНОЙ ЭКОЛОГИЧЕСКОЙ ЗОНЫ БАЙКАЛЬСКОГО РЕГИОНА (на территории Республики Бурятия)
}

\section{Л. Л. Убугунов, И. А. Белозерцева, В. И. Убугунова, А. А. Сороковой}

\section{(C) Убугунов Леонид Лазаревич}

доктор биологических наук, профессор,

Институт общей и экспериментальной биологии СО РАН

Россия, 670047, г. Улан-Удэ, ул. Сахьяновой, 6

Бурятская государственная сельскохозяйственная академия им. В. Р. Филиппова

Россия, 670042, г. Улан-Удэ, ул. Пушкина, 8

1-ulze@mail.ru

(C) Белозерцева Ирина Александровна

кандидат географических наук,

Институт географии им. В. Б. Сочавы СО РАН

Россия, 664033, г. Иркутск, ул. Улан-Баторская, 1

Иркутский государственный университет

Россия, 664011, г. Иркутск, Сухэ-Батора, 5

belozia@mail.ru

\section{(C) Убугунова Вера Ивановна}

доктор биологических наук, профессор,

Институт общей и экспериментальной биологии СО РАН

Россия, 670047, г. Улан-Удэ, ул. Сахьяновой, 6

ubugunova57@mail.ru

\section{(C) Сороковой Андрей Анатольевич}

кандидат географических наук,

Институт географии им. В. Б. Сочавы СО РАН

Россия, 664033, г. Иркутск, ул. Улан-Баторская, 1

geomer@irigs.irk.ru

Аннотация. В результате многолетних исследований на основе единых методологических и классификационных подходов изучены эколого-географические закономерности распределения почв Центральной экологической зоны Байкальского региона на территории Республики Бурятия и проведено картирование почвенного покрова. На данном этапе исследований выделено 38 типов почв, объединенных в 18 почвенных контурах. Определены их территориальное распространение и проведена площадная оценка почвенных ресурсов. Показано доминирующее влияние высотно-вертикальной поясности в пространственном распределении почв, что связано с горным рельефом исследованного региона. Установлено, что почвы горно-тундровой зоны

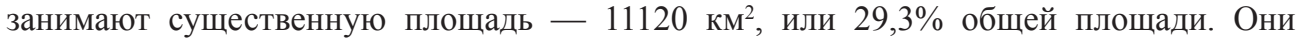


преимущественно представлены слаборазвитыми почвами - литоземами и петроземами с сопутствующими им почвами и глееземами с торфяно-глееземами и торфяно-литоземами. Также выявлены пленочные «почвоподобные» тела. Большая часть исследуемой территории (53,8\% общей площади) занята почвами среднегорья, где преобладают подбуры, буроземы, дерново-подбуры, подзолы, дерново-подзолы, буроземы грубогумусовые и др. Существенное участие подбуров в почвенном покрове среднегорий связано с распространением известково-щелочных Ангаро-Витимских батолитов, препятствующих элювиальной дифференциации почв, а буроземов - с формированием «теплых» ландшафтов под влиянием отепляющего эффекта водных масс оз. Байкал. Также встречаются темногумусовые, перегнойно-темногумусовые, торфянокриоземы, торфяно-подбуры глеевые и др. В низкогорьях доминирующими почвами являются подзолы и дерново-подзолы глеевые с сопутствующими им дерново-

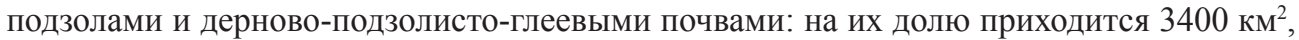
или $8,9 \%$ общей площади. В межгорных котловинах господствующее положение принадлежит серым метаморфическим почвам, дерново-подбурам с дерново-серыми почвами, а также псаммоземам гумусовым: в целом они занимают 594 км². Северная и северо-восточная части территории характеризуются господством в автоморфных условиях подзолов и подбуров со слабодифференцированным профилем, что обусловлено большой распространенностью известково-щелочных батолитов. На восточном побережье Байкала, как на равнине, так и в предгорной полосе, распространены дерново-подзолистые почвы. К выходам мраморов и их дериватов приурочены темногумусовые и серогумусовые почвы, занимающие небольшую часть территории ЦЭЗ. В пойменно-дельтовых ландшафтах и в устьях рек формируются различные комплексы аллювиальных почв, а на болотных и заболоченных массивах получили развитие торфяные эутрофные почвы, торфяно-глееземы и др. Территории вокруг озер преимущественно заняты темногумусовыми глеевыми и торфяными эутрофными почвами, а в местах впадения в озера или вытекания из них рек и речек - аллювиальные почвы. В целом на долю болотных и аллювиальных почв приходится 2405 км² (6,3\% общей площади почв ЦЭ3). Засоленные почвы занимают крайне незначительные площади: они встречаются только вблизи минеральных источников.

Ключевые слова: почвы; картографирование; почвенные ресурсы; Байкальский регион; центральная экологическая зона; Республика Бурятия.

\section{Для цитирования}

Эколого-географические закономерности распределения почв и почвенные ресурсы центральной экологической зоны Байкальского региона (на территории Республики Бурятия) / Л. Л. Убугунов [и др.] // Природа Внутренней Азии. Nature of Inner Asia. 2020. № 2(15). С. 37-54. DOI: 10.18101/2542-0623-2020-2-37-54

\section{Введение}

Всестороннее изучение функционирования экосистемы озера Байкал, являющегося с 1996 г. по решению ЮНЕСКО одним из участков Мирового природного наследия, и его водосборных ландшафтов является важнейшей задачей не только для России, но и для всего человечества. Это связано с тем, что запасы пресной воды в озере представляют собой важнейший стратегический ресурс планеты. Весьма значима роль оз. Байкал и как места организации зоны рекреации планетарного значения и в ближайшем будущем строжайшего экологически ориентированного землепользования и бизнеса. 
Л. Л. Убугунов, И. А. Белозериева, В. И. Убугунова, А. А. Сорокова. Эколого-географические закономерности распределения почв и почвенные ресурсы центральной экологической зоны...

В последние десятилетия в береговой зоне и непосредственно прилегающих к ней территориях заметно возрастает антропогенная нагрузка, связанная с резким усилением использования лесных, пастбищных, животных (в первую очередь рыбных) и других природных ресурсов. Также существенно усилилось рекреационное воздействие из-за увеличения количества туристических баз, домов отдыха, пансионатов и непомерной активизации практически неконтролируемого «дикого» туризма. Негативный антропогенный пресс в центральной экологической зоне (ЦЭЗ) Байкальского региона особенно наглядно проявляется на административно расположенных в Республике Бурятия (РБ) территориях: прибрежных участках южного, юго-восточного и частично северного Байкала, в Чивыркуйском заливе, в устьях рек Селенга, Баргузин, Верхняя Ангара, на северо-восточном побережье, где располагается ряд санаторно-курортных зон с минеральными источниками, на оз. Котокельское. Выявлена деградация прибрежных водных экосистем в связи с загрязнением органогенными и минеральными веществами и другими различными отходами, зарастанием элодеей канадской, спирогирой, изменением видового состава микроорганизмов, флоры, животного мира [Озеро Котокельское... 2013; Тимошкин и др., 2014; Потапская и др., 2016; Сутурин и др., 2016 и др.]. Антропогенное воздействие негативно сказывается и на расположенные рядом наземные ландшафты из-за различных социально-деструктивных процессов: эрозионных, гидроморфных (подтопление, заболачивание), фитодеградационных, рекреационных, техногенных [Убугунов и др., 2016]. Возрастают площади экосистем, трансформированных лесными и торфяными пожарами, интенсивными вырубками лесов, экологически нерегулируемым сельскохозяйственным использованием почвенно-растительного покрова [Убугунов и др., 2015; Экологический ... 2015; Гынинова и др., 2020 и др.].

Почва, как известно, является связующим звеном абиотических и биотических компонентов экосистем [Добровольский, Никитин, 2012], носителем информации о функционировании и формировании ландшафта [Козловский, Горячкин, 2008], его своеобразным «зеркалом». В связи с этим для комплексной оценки разнообразия, состояния и устойчивости экосистем крайне необходимы сведения о почвенном покрове. В научной литературе имеются материалы по почвам дельты р. Селенги [Петрович, 1974; Убугунов и др., 2013; Гынинова и др., 2012] и водосборной площади оз. Котокельское [Озеро ... 2013; Балсанова и др., 2014]. За последние годы получены новые сведения по основным закономерностям формирования и пространственного распределения почв этой территории [Белозерцева и др., 2016], почвам полуострова Святой Нос [Балсанова и др., 2017], бассейну рек Давша [Цыбикдоржиев и др.,2017] и Сухая [Цыбикдоржиев, Бадмаев, 2019]. Однако до настоящего времени целенаправленных исследований по почвам ЦЭЗ бассейна оз. Байкал на территории РБ не проводилось. В связи с вышесказанным актуальными являются комплексное изучение и оценка современного состояния всего почвенного покрова данного природно-территориального региона с целью дальнейших экологических мониторинговых наблюдений и разработки мероприятий по охране и рациональному использованию почвенно-земельных ресурсов в республике.

Цель данного исследования - изучение разнообразия почв, их экологогеографических закономерностей распределения, составление почвенной карты 
и оценка площадного (ресурсного) потенциала почвенного покрова в ЦЭЗ бассейна оз. Байкал на территории Бурятии.

\section{Объекты и методы исследований}

В основу статьи положены многолетние исследования авторов, проведенные в 2010-2019 гг. в центральной экологической зоне Байкальского региона, находящейся на территории Бурятии. В этот регион по экологическому зонированию включены: 1) озеро Байкал с островами (Ушканьи и ряд мелких островов); 2) заповедники: Байкальский и Баргузинский; 3) Забайкальский национальный парк; 4) заказники: Степнодворецкий, Кабанский, Энхэлукский, Прибайкальский, Фролихинский и Верхне-Ангарский; 5) водоохранная зона озера Байкал [Плюснин, Владимиров, 2013]. Использовались результаты традиционно-классических и современных почвенно-географических, морфологических, классификационных, обзорно-аналитических, опытно-агрохимических и лабораторно-аналитических методов исследований. За период полевых работ было отобрано более 500 почвенных образцов. В почвах опорных разрезов определены морфологические, физико-химические и химические свойства общепринятыми в почвоведении методами. Пробоподготовка и выполнение всех необходимых анализов проводились в Химико-аналитическом центре Института географии им. В. Б. Сочавы СО РАН и в Институте общей и экспериментальной биологии СО РАН по общепринятым методикам. Химико-аналитический центр ИГ СО РАН лицензирован и входит в Центр коллективного пользования ИНЦ СО РАН. Почвы систематизированы в соответствии с Классификацией почв России [Классификация... 2004; Полевой... 2008].

\section{Эколого-географические условия почвообразования}

Особенностью ЦЭЗ Байкальского региона на территории РБ является смена на небольших расстояниях геологического и геоморфологического строения, климатических показателей, растительного покрова [Экологический... 2015].

Кроме того, исследованный регион является центральным участком Байкальского внутриконтинентального рифта и представляет собой контактную зону двух контрастных по температурным и механическим свойствам литосферных мегаблоков Сибирской платформы и Центрально-Азиатского подвижного пояса [Логачев, 1974; Мац, 2015]. Это самая крупная «живая» тектоническая структура Евразийского континента, характеризующаяся высокой тектонической активностью, интенсивной сейсмичностью и высоким метаморфизмом [Донская и др., 2000].

Геологическому строению свойственно большое разнообразие коренных пород: сложные тектонические движения и метаморфизм способствовали распространению метаморфических, осадочных и магматических пород различного возраста [Салоп, 1967]. Среди них преобладают граниты, гранитоиды гранодиоритовой модели известково-щелочного генезиса [Литвиновский и др., 1993; Рыцк и др., 1998]. К северной оконечности озера приурочены массивы основных и ультраосновных пород. Разные свиты протерозойского и кембрийского возраста, содержащие карбонатные породы, простираются вдоль Приморского хребта, обрываются к Предбайкальской впадине, окаймляют с севера Байкало-Патомское нагорье. В межгорных понижениях и широких речных долинах развита мощная толща 
Л. Л. Убугунов, И. А. Белозериева, В. И. Убугунова, А. А. Сорокова. Эколого-географические закономерности распределения почв и почвенные ресурсы центральной экологической зоны...

рыхлых песчаных и супесчаных отложений. Низкие речные террасы сложены современным речным аллювием песчано-галечникого и песчано-глинисто-иловатого состава. В аллювиальных отложениях узких долин малых рек обнаруживается большое содержание галечника и валунов. Понижения вокруг озер выполнены, как правило, озерными песчаными и супесчаными продуктами выветривания. Для почвообразующих пород рассматриваемой территории свойственно высокое содержание первичных и незначительное - вторичных минералов и характерны преимущественно легкий гранулометрический состав и высокая скелетность, что является признаком их слабой выветрелости.

Рельеф изученной территории преимущественно горный и представляет собой сложно построенную систему высокогорных и среднегорных четко выраженных хребтов и глубоких межгорных впадин [Логачев, 1974]. Линейные морфоструктуры ограничены зонами глубинных разломов, что определило неоднородность геоморфологического строения на небольших расстояниях. Среди хребтов выделяются Баргузинский (до 2700 м), Морской (до 1700 м) и Хамар-Дабан (до 2300 м) и на северо-западе частично Байкальский (до 2500 м). Самой низкой отметкой является уровень оз. Байкал - 456 м над ур. м. Из отрицательных морфоструктур наиболее крупной является Усть-Селенгинская впадина. Морфологически она представляет собой достаточно ровную заболоченную низину с небольшими старицами, протоками, озерами и песчаными террасами. Общая площадь впадины

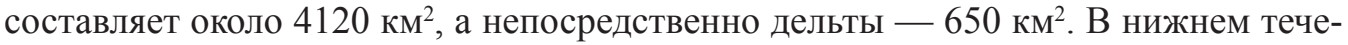
нии р. Баргузин расположена Усть-Баргузинская впадина с максимальными размерами депрессии 45 км на 40 км. Она состоит из аллювиально-озерных равнин, грядово-холмистых грядовых массивов и предгорных наклонных равнин. Границы Северо-Байкальской впадины имеют сложные очертания, но в целом приурочены к нижнему течению и устьям рек Верхняя Ангара и Кичера и их крупным притокам. Ее северо-восточная часть представляет собой полигенетическую равнину, частично перекрытую моренами и водно-ледниковыми образованиями, а к югу и юго-востоку она переходит в полузатопленную аллювиально-озерную равнину с комплексом озерных и речных террас [Резанов, Резанова, 2009].

Климат изученной территории континентальный. Это проявляется в уменьшении амплитуд сезонных и суточных колебаний температуры. Огромные водные массы озера оказывают отепляющий эффект и способствуют формированию своеобразного лимноклимата [Ладейщиков, 1976]. Отепляющее влияние озера распространяется на 50-60 км прибрежной территории с августа по январь. Охлаждающее влияние проявляется только на расстоянии до 5-6 км от озера с февраля по июль [Атлас... 1990]. Количество выпадающих атмосферных осадков достаточно высокое, особенно на наветренных склонах Баргузинского хребта и хребта Хамар-Дабан, где оно достигает 800-1200 мм. Отчетливо выражены широтные различия между северными и южными участками территории по среднегодовой температуре, увеличению континентальности. Сложное орографическое строение территории влияет на циркуляцию воздушных масс и создает неоднородность параметров тепло- и влагообеспеченности на наветренных склонах и межгорных впадинах [Буфал и др., 1976].

По соотношению тепла и влаги создаются условия для высотной дифференциации растительности на тундровую и таежно-лесную [Моложников, 1986]. 
Особенностью ЦЭЗ Байкальского региона на территории Бурятии является формирование своеобразного «влажного прибайкальского» ложноподгольцового пояса на предгорной части Баргузинского хребта [Тюлина, 1976] и ХамарДабана [Епова, 1960]. Температурные инверсии и ветровой режим способствуют «переселению» некоторых тундровых видов на прибрежные равнинные участки, а также сохранению реликтов третичной флоры [Чепинога и др., 2017]. Луговая растительность в Прибайкалье занимает небольшие площади, но отличается довольно высоким разнообразием, т. к. можно выделить настоящие, остепненные, болотистые и торфянистые луга. В низовьях крупных рек (Селенги, Баргузина) существенные площади заняты различными болотистыми осоково-разнотравными лугами с водолюбами (Eleocharis) и ситником (Juncus). Болотная растительность в низовьях Селенги, Верхней Ангары, Баргузина, Турки представляет собой сложный комплекс из торфянистых и болотистых лугов, заболоченных лесов, кустарниковых сообществ, а также гидрофильно-моховых ассоциаций из сфагновых и гипновых мхов. На Посольском болотном массиве в приустьевой впадине p. Селенги произрастают характерные осоково-зеленомошные группы формаций, приуроченные к топям и способствующие формированию низинного торфяника [Аненхонов, Бойков, 2009].

\section{Результаты и обсуждение}

В целях более детального изучения почв непосредственно «прибайкальских» территорий нами на основе анализа проведенных ранее научных исследований и картографических работ, в том числе и наших [Почвенный ... 1980; Цыбжитов, Цыбжитов, 2000; Убугунов и др., 2012; Убугунов и др., 2018а,б; Белозерцева и др., 2016; Белозерцева и др., 2018 и др.], была составлена на базе новой классификации почв почвенная карта ЦЭЗ бассейна оз. Байкал на территории Республики Бурятия (рис., табл.). Классификация и номенклатура почв даны по современной классификации России [Классификация..., 2004].

По современному почвенно-экологическому районированию почвенный покров исследованного региона входит в Северо-Восточно-Байкальскую, ХамарДабанскую и частично в Прибайкальскую провинции и в выделенные на их территориях округа [Убугунов и др., 2019а,б].

\section{Почвы высокогорий}

Проведенные ранее исследования в Байкальском регионе выявили доминирующее влияние высотно-вертикальной поясности при слабо выраженной широтной зональности [Белозерцева и др., 2016; Убугунов и др., 2018 а,б]. Эта же закономерность, как нами установлено, выражена и на исследованной территории. Особенно отчетливо это проявляется в тундровой зоне, которая занимает самый верхний пояс прилегающих к оз. Байкал горных массивов (от 1600 до 2000 м над ур. м.) и занимает достаточно большую площадь (11120 км², или 29,3 \% общей площади почвенного покрова региона). Ареалы с тундровыми почвами разбросаны небольшими контурами в высокогорной части Байкальского и Баргузинского хребтов, Хамар-Дабана и полуострова Святой Нос (рис.). Проведенными исследованиями выявлено, что, несмотря на широкую пространственную разобщенность, наблюдается существенная однотипность почвенного покрова высокогорной части. 
Л. Л. Убугунов, И. А. Белозериева, В. И. Убугунова, А. А. Сорокова. Эколого-географические закономерности распределения почв и почвенные ресурсы центральной экологической зоны...

На повышенных элементах рельефа водоразделов тундровой зоны получают развитие литоземы (отдел литоземы, постлитогенный ствол) и сопутствующие с ними неполнопрофильные сильноскелетные петроземы (отдел слаборазвитых почв, первичный ствол почвообразования). Они распространены, как правило, на сложенных щебнистым материалом горных породах и обладают свободным внутренним дренажем. Формирование данных почв происходит в суровых климатических условиях, при высокой активности физического выветривания и низкой - химического и биологического. В результате этих процессов в них отмечается большое количество грубообломочного слабо выветренного материала. Вместе с подбурами данные почвы занимают площадь, равную примерно

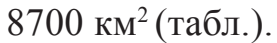

Следует отметить, что в тундровой зоне почвы формируются только на участках с мелкоземом, а на выходах плотных скальных пород и крупно-глыбистых каменистых россыпях встречаются пленочные почвоподобные образования. Их относят к особой группе «почв» (солоидам), формирующихся в экстремальных условиях [Семиколенных, Таргульян, 2010; Горячкин и др., 2019; Beyer, Boelter, 2002; Bockhein, 2015; Mergelovetal, 2018]. В высокогорной части исследованного региона эти маломощные образования формируются на скалисто-каменистых выходах при сочетании следующих неблагоприятных для развития почв факторов: недостатка биологически активных температур, заторможенности химического и биологического выветривания, высокой каменистости, практического отсутствия мелкозема и очень слабого воздействия на процессы почвообразования бескорневой растительности. На данном этапе исследований почвоподобные тела конкретно не учитывались при расчете площадей и вошли в почвенные комплексы с литоземами и петроземами (контуры 1 и 2).

В северо-восточной части ЦЭЗ выделен небольшой по площади участок,

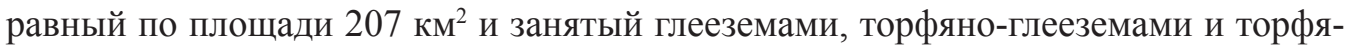
но-литоземами (контур 3) (рис.). Они распространены на породах более тяжелого гранулометрического состава. Развитию глеевого процесса способствует длительное сохранение мерзлоты как водоупора и переувлажнение. Подобные почвы встречаются и на других хребтах, но крайне незначительно, и картографически не отображены.

На хребтах Станового нагорья самостоятельную полосу, особенно четко выраженную на западной окраине, вблизи тектонического уступа к Предбайкальской впадине, занимают заросли стланика с литоземами, петроземами, подбурами и подзолами среди каменистых россыпей. Проведенные здесь исследования свидетельствуют о разреженности кедрово-стланиковых зарослей и их близости к гольцам.

В высокогорной части Верхне-Ангарского и Баргузинского хребтов также формируются петроземы, торфяно-литоземы и литоземы грубогумусные, под субальпийскими лугами - грубогумусовые, перегнойные и перегнойно-темногумусовые почвы. На северных склонах, в относительно пониженных элементах рельефа, и на участках, сложенных почвообразующими породами более тяжелого гранулометрического состава, формируются подбуры глеевые, для которых характерны длительное сохранение мерзлотного экрана и связанные с этим процессы переувлажнения и оглеения. Эта территория оценена нами как переходная от почв высокогорий к почвам среднегорий. 
NATURE OF INNER ASIA

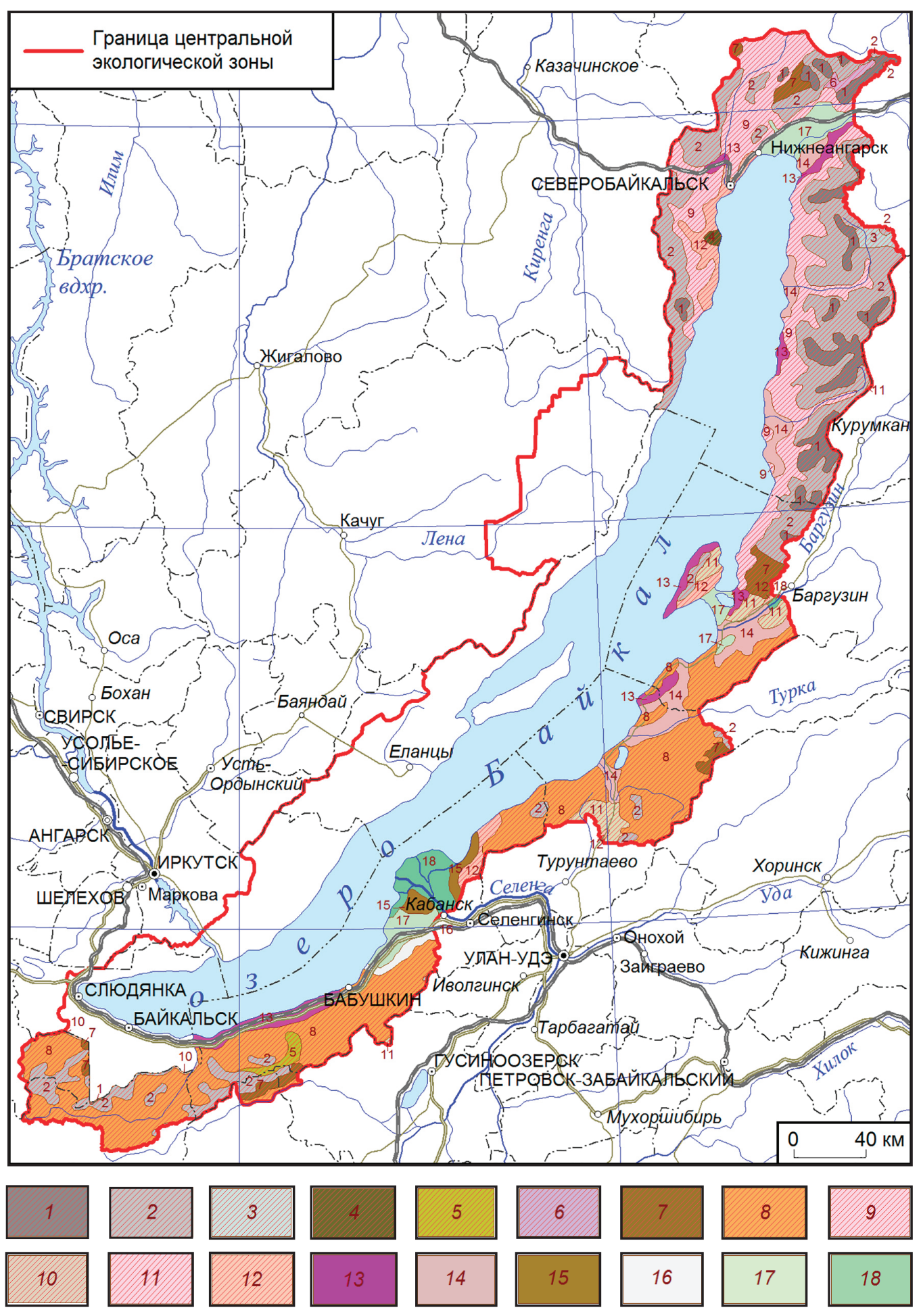

Puc. Почвы центральной экологической зоны Байкальского региона (на территории Республики Бурятия) 
Легенда к карте «Почвы центральной экологической зоны Байкальского региона (на территории Республики Бурятия)» и площадное распространение почв

\begin{tabular}{|c|c|c|c|c|c|}
\hline \multicolumn{6}{|c|}{ Почвы } \\
\hline $\begin{array}{l}\text { № } \\
\text { кон- } \\
\text { тура }\end{array}$ & Основные почвы & $\begin{array}{c}\text { Сопутствующие } \\
\text { (около 15-20\% } \\
\text { к площади контура) }\end{array}$ & $\begin{array}{l}\text { Встречающиеся } \\
\text { (около 5-10\%) }\end{array}$ & $\kappa M^{2}$ & $\%$ \\
\hline \multicolumn{6}{|c|}{ Почвы высокогорий } \\
\hline 1 & $\begin{array}{l}\text { литоземы, } \\
\text { петроземы }\end{array}$ & криоземы, подбуры & глееземы, подзолы & 2224 & 5,9 \\
\hline 2 & литоземы & петроземы & подбуры & 8689 & 22,9 \\
\hline 3 & глееземы & торфяно-глееземы & торфяно-литоземы & 207 & 0,6 \\
\hline \multicolumn{6}{|c|}{ Почвы среднегорий } \\
\hline 4 & темногумусовые & $\begin{array}{l}\text { перегнойно- } \\
\text { темногумусовые }\end{array}$ & перегнойные & 64 & 0,2 \\
\hline 5 & $\begin{array}{l}\text { перегнойно- } \\
\text { темногумусовые }\end{array}$ & \begin{tabular}{|l|} 
перегнойно- \\
криометаморфические
\end{tabular} & перегнойные & 225 & 0,6 \\
\hline 6 & торфяно-криоземы & $\begin{array}{l}\text { торфяно-подбуры } \\
\text { глеевые }\end{array}$ & торфяно-глееземы & 137 & 0,4 \\
\hline 7 & \begin{tabular}{|l} 
подбуры (подтип \\
- грубогумусовые) \\
\end{tabular} & \begin{tabular}{|l|} 
дерново-подбуры, \\
сухоторфяно-подбуры
\end{tabular} & буроземы грубогумусовые & 970 & 2,5 \\
\hline 8 & $\begin{array}{l}\text { подбуры, буроземы } \\
\text { грубогумусовые }\end{array}$ & дерново-подбуры & подзолы & 10953 & 28,9 \\
\hline 9 & подбуры, подзолы & дерново-подзолы & дерново-подбуры & 5996 & 15,8 \\
\hline 10 & буроземы & подбуры & подзолы & 45 & 0,1 \\
\hline 11 & $\begin{array}{l}\text { подбуры, } \\
\text { грубогумусовые }\end{array}$ & $\begin{array}{l}\text { дерново-подзолы, } \\
\text { буроземы грубо- } \\
\text { гумусовые } \\
\end{array}$ & подзолы & 870 & 2,3 \\
\hline 12 & дерново-подбуры & серогумусовые & $\begin{array}{l}\text { литоземы серогумусовые, } \\
\text { петроземы гумусовые }\end{array}$ & 1144 & 3,0 \\
\hline \multicolumn{6}{|c|}{ Почвы низкогорий и межгорных понижений } \\
\hline 13 & подзолы & дерново-подзолы & подзолистые & 1356 & 3,6 \\
\hline 14 & $\begin{array}{l}\text { дерново-подзолы } \\
\text { глеевые }\end{array}$ & $\begin{array}{l}\text { дерново-подзолисто- } \\
\text { глеевые }\end{array}$ & дерново-подзолы глееватые & 2046 & 5,4 \\
\hline 15 & $\begin{array}{l}\text { дерново-подбуры, } \\
\text { дерново-серые }\end{array}$ & \begin{tabular}{|l} 
псаммоземы \\
гумусовые
\end{tabular} & темногумусовые & 359 & 0,9 \\
\hline 16 & $\begin{array}{l}\text { серые } \\
\text { метаморфические }\end{array}$ & дерново-серые & серогумусовые & 235 & 0,6 \\
\hline \multicolumn{6}{|c|}{ Почвы пойм и дельт рек, вблизи болот и озер } \\
\hline 17 & $\begin{array}{l}\text { торфяные } \\
\text { эутрофные }\end{array}$ & торфяно-глееземы & $\begin{array}{l}\text { перегнойно-глеевые, } \\
\text { торфяно-глееземы, } \\
\text { торфяно-криоземы }\end{array}$ & 1552 & 4,1 \\
\hline 18 & $\begin{array}{l}\text { аллювиальные } \\
\text { темногумусовые, } \\
\text { аллювиальные } \\
\text { темногумусовые } \\
\text { глеевые }\end{array}$ & $\begin{array}{l}\text { слоисто-аллювиаль- } \\
\text { ные, аллювиальные } \\
\text { темногумусовые }\end{array}$ & $\begin{array}{l}\text { перегнойно-глеевые, } \\
\text { торфяно-глеевые }\end{array}$ & 853 & 2,2 \\
\hline & & & В с его & 37925 & 100 \\
\hline
\end{tabular}




\section{Почвы среднегорий}

Структура почвенного покрова в этой природно-климатической зоне неоднородная, т. к. во многом связана с проявлением вертикальной поясности, экспозицией склонов, многолетней мерзлотой и другими эколого-географическими факторами почвообразования. На долю почв среднегорий в ЦЭЗ бассейна оз. Байкал в РБ приходится 20404 км², или 53,8 \% общей площади (табл.).

Основной фон почв, преимущественно на хребтах Морской и Хамар-Дабан, составляют комплексы подбуров с буроземами грубогумусовыми с сопутствующими им дерново-подбурами и встречающимися подзолами: они занимают около 11 тыс. км², или 28,9 \% (рис., табл.). Обращает на себя внимание существенное участие почв с недифференцированным профилем - подбуров [Цыбикдоржиев, Бадмаев, 2018]. В значительной степени это связано с большой распространенностью пород Ангаро-Витимского батолита, имеющих известково-щелочной состав пород [Литвиновский и др., 1993] и препятствующих формированию элювиальной дифференциации.

Характерной особенностью почвенного покрова прибайкальских склонов являются буроземы грубогумусовые. Они приурочены к суглинистым отложениям. Для них характерен грубогумусовый горизонт (AO), маломощный темный гумусовоаккумулятивный, хорошо оструктурированный горизонт (AU) с высоким содержанием гумуса. Метаморфический горизонт хорошо выражен, имеет ореховатокомковатую структуру, повышенное содержание ила и подвижных оксидов железа. Формированию этого типа почв способствует континентальный климат, благодаря которому увеличивается продолжительность биологически активных температур и, соответственно, период процессов выветривания и метаморфизма. Наиболее широкий ареал буроземов грубогумусных встречается в среднегорной части хребта Хамар-Дабана (контур 10) (рис.). В этом районе почвы формируются в условиях непромерзающего температурного режима. Минимальная температура зарегистрирована только в поверхностном $0-5$ см слое почвы в марте $\left(+0,5^{\circ} \mathrm{C}\right)$. Это, конечно, феномен для Сибири с ее длительно-сезонными и мерзлотными почвами [Убугунова, 1987; Цыбжитов, Убугунова, 1992], а локальная гумидность почвенного климата создает благоприятные условия для произрастания пихтовых лесов крупнотравной и папоротниковой групп типов леса, которые представляют собой микрорефугиумы для ряда растений [Чепинога и др., 2017].

Следующим по площади контуром (около 6 тыс. км², или 15,8\%) являются ареалы с доминированием почв альфегумусового отдела: подбурами и подзолами с дерново-подзолами и дерново-подбурами (контур 9). Эти почвы в большей степени развиты на Верхнеангарском и Баргузинском хребтах и на БайкалоПатомском нагорье (рис.) и характеризуются как наиболее типичные почвы лесных ландшафтов с выраженным альфегумусовым процессом [Цыбикдоржиев и др., 2017]. В целом на долю этих двух контуров (8 и 9) приходится 44,7 \% общей площади почв исследованного региона. Территории же, занимаемые другими типами почв, незначительны (табл.).

Под субальпинотипными лугами, преимущественно произрастающими на хребте Хамар-Дабан, формируются темногумусовые, перегнойно-темногумусовые и перегнойно-криометаморфические почвы (контуры 4 и 5) (рис.), но ареал 
Л. Л. Убугунов, И. А. Белозериева, В. И. Убугунова, А. А. Сорокова. Эколого-географические закономерности распределения почв и почвенные ресурсы центральной экологической зоны...

их распространения в площадном выражении незначителен и занимает менее $1 \%$ общей площади почв (табл.).

В переходной полосе от гольцов к тайге существенную роль играет кустарниковый и мохово-лишайниковый покровы, а доля древесной растительности незначительна. Здесь под кедрово-стланиковыми зарослями и подгольцовым редколесьем получают незначительное по площади $\left(137 \mathrm{км}^{2}\right)$ развитие торфяно-криоземы с торфяно-подбурами глеевыми (контур 6). Преимущественно они формируются на Байкальском хребте (рис.). Основной тип метаморфизма в этих почвах связан с верхними органогенными горизонтами и частично с преобразованием почвенной толщи при мерзлотных процессах. Более широкое развитие получили подбуры грубогумусовые с дерново-подбурами и сухоторфяно-подбурами (контур 7, табл.). На Морском хребте и полуострове Святой Нос выделены комплексы почв с преобладанием подбуров грубогумусовых с сопутствующими дерново-подзолами и буроземами грубогумусовыми (контур 11) (рис.). Также в среднегорных ландшафтах ЦЭЗ БПТ в Бурятии формируются дерново-подбуры с серогумусовыми почвами (контур 12): они распространены в непосредственно примыкающей к озеру северо-западной части зоны и на юго-западных отрогах Морского хребта (рис.).

\section{Почвы низкогорий и межсгорных понижений}

Основными почвами низкогорий являются подзолы и дерново-подзолы глеевые с сопутствующими им дерново-подзолами и дерново-подзолисто-глеевыми почвами (контуры 13 и 14). В комплексе с ними встречаются подзолистые почвы и дерново-подзолы глееватые (рис.). Территория, занимаемая всеми этими почвами,

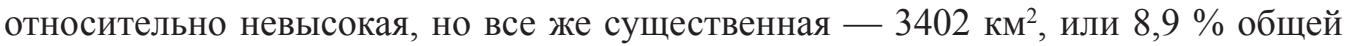
площади (табл.).

Межгорные понижения в исследованном регионе занимают незначительную территорию и расположены в долинах нижнего течения и в устьях крупных и средних рек. Господствующее положение в них занимают серые метаморфические почвы и дерново-подбуры с дерново-серыми почвами (контуры 15 и 16) (рис.).

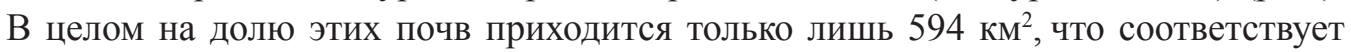
$1,5 \%$ территории ЦЭЗ в РБ (табл.). Они формируются преимущественно на подгорных участках котловин и речных долин и северных склонах сопок, находящихся внутри межгорных понижений и в нижней части облесенных склонов хребтов, обращенных к степным котловинам. Совместно с ними развиваются псаммоземы гумусовые, а также встречаются темно- и серогумусовые почвы.

Следует отметить, что дерново-серые почвы высоких и древних плиоценплейстоценовых террас, прислоненных к хребту Морскому и останцам ТвороговоИстокского поднятия под редкотравными сосняками, сосново-березовыми и березовыми лесами, имеют сложный генезис [Линник, 1978; Цыбжитов Ц. Х., Цыбжитов А. Ц., 2000; Болонева, Корсунов, 2008]. Почвенный профиль характеризуется слабой дифференциацией на генетические горизонты и практическим отсутствием оструктуренности. Для его срединой части характерны однородная светлобурая или палевая окраска и отсутствие процессов метаморфизма. Эти почвы имеют определенное сходство с палево-бурыми почвами Якутии [Гынинова, Балсанова, 2009]. По мнению А. Б. Гыниновой с соавторами [2012] и авторов 
данного сообщения, мало- и среднегумусные дерново-серые почвы по ряду признаков аналогичны серогумусовым, а многумусные имеют ряд общих черт с буроземами. По системе генетических горизонтов и свойствам эти почвы не имеют адекватных вариантов в Классификации почв России (2004) и международной классификации WRB (2015). На данном этапе исследований было решено оставить предложенное Ц. Х. Цыбжитовым, А. Ц. Цыбжитовым [2000] название дерново-серые почвы.

\section{Почвы пойм и дельт рек, вблизи болот и озер}

Пространственная организация почвенного покрова этих территорий формируется в пойменных, дельтовых, заболоченных и приозерных ландшафтах тектонических понижений Прибайкалья с соответствующим им разнообразием факторов почвообразования [Гынинова и др., 2012; Убугунов и др., 2013].

В поймах нижнего течения крупных и средних рек, их устьях и дельтах преимущественно распространены различные комплексы аллювиальных темногумусовых и аллювиальных темногумусовых глеевых почв со слоисто-аллювиальными, перегнойно-глеевыми и торфяно-глеевыми почвами (контур 18) (табл.). В структуре почвенного покрова островов и пойменных ландшафтов верхнего и среднего течения рек в относительно большей степени развиты слоисто-аллювиальные почвы первичного ствола почвообразования. Преобладающими почвами современной дельты р. Селенги («дельта выдвижения») с постоянным затоплением паводковыми водами являются слоисто-аллювиальные гумусовые почвы первичного ствола почвообразования. В почвах с грунтовым увлажнением получают развитие аллювиальные темногумусовые почвы. На пониженных участках пойменно-дельтового рельефа в условиях постоянного избыточного увлажнения в результате развития процессов торфообразования и глеевого формируются аллювиальные торфянои перегнойно-глеевые почвы. В долине р. Баргузин развиты аллювиальные темногумусовые почвы, а при близко залегающей мерзлоте - торфяно-глееземы и аллювиальные (торфяно-)перегнойно-глеевые почвы. В дельте р. Верхняя Ангара преобладают торфяные эутрофные, торфяно-глееземы и перегнойно-глеевые почвы.

На болотных массивах исследованной территории (Калтуский массив, Кулиные болота, болота перешейка Святого Носа, сфагновые болота Ангаро-Кичерской дельты с прилегающими к ним болотами в долине реки Кичеры) формируются в основном торфяные эутрофные почвы, торфяно-глееземы и встречаются перегнойно-глеевые почвы, торфяно-глееземы и торфяно-криоземы (контур 17) (рис., табл.).

Приозерные территории в исследованной зоне заняты темногумусовыми глеевыми и торфяными эутрофными почвами, а в местах впадения в озера или вытекания из них рек и речек - различными типами аллювиальных почв [Убугунов и др., 2013; Балсанова и др., 2014]. Как правило, комплексы приозерных почв занимают незначительные площади, поэтому в масштабе карты не выражены. Также следует отметить, что в исследованном регионе практически не отмечено наличие засоленных почв, кроме очень малых по площади территорий, связанных с выходами различных минеральных источников. В целом на долю почв речных пойм,

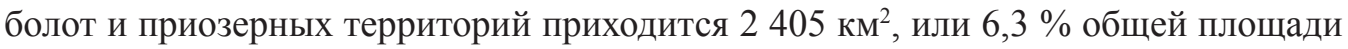
почв ЦЭЗ (табл.). 
Л. Л. Убугунов, И. А. Белозериева, В. И. Убугунова, А. А. Сорокова. Эколого-географические закономерности распределения почв и почвенные ресурсы центральной экологической зоны...

\section{Заключение}

Разнообразие почв Центральной экологической зоны Байкальского региона на территории Республики Бурятия на данном этапе исследований представлено 38 типами почв. Данные почвы распределены в высоко-, средне- и низкогорьях, межгорных понижениях, поймах и дельтах рек, вблизи болот и озер и включены в состав 18 почвенных контуров.

Почвы высокогорий представлены слаборазвитыми почвами - литоземами и петроземами с сопутствующими им почвами. На выходах скальных пород и крупно-глыбистых каменистых россыпях встречаются пленочные «почвоподобные» тела. На породах более тяжелого гранулометрического состава в условиях длительного сохранения мерзлоты и переувлажнения формируются глееземы с торфяно-глееземами и торфяно-литоземами, но площадь их распространения незначительна. Ареалы с почвами горно-тундровой зоны занимают в целом относительно большую площадь - 11120 км², или 29,35 общей площади исследованного региона.

Почвы среднегорий занимают более половины общей площади ЦЭЗ БПТ в Бурятии (53,8\%). Преимущественно здесь формируются подбуры, буроземы, а также подзолы, дерново-подзолы и дерново-подбуры: на их долю приходится $44,7 \%$ общей площади. Существенное участие подбуров в почвенном покрове среднегорий связано с большой распространенностью известково-щелочных пород Ангаро-Витимского батолита, препятствующих формированию элювиальной дифференциации почв. Особенностью прибайкальских склонов, особенно на Хамар-Дабане, Баргузинском, Морском хребтах и полуострове Святой Нос, являются буроземы грубогумусовые. Территории, занимаемые другими типами почв в среднегорьях, незначительны. В площадном отношении выделены контуры темногумусовых и перегнойно-темногумусовых почв, торфяно-криоземов с торфяно-подбурами глеевыми. Определенное распространение имеют подбуры грубогумусовые с сопутствующими дерново-подбурами, сухо-торфяно-подбурами, дерново-подзолами и буроземами грубогумусовыми. В непосредственно примыкающей к озеру северо-западной части ЦЭЗ и на юго-западных отрогах Морского хребта формируются дерново-подбуры с серогумусовыми почвами.

Почвы низкогорий и межгорных понижений также характеризуются значительным разнообразием. Преобладающими почвами низкогорий являются подзолы и дерново-подзолы глеевые с сопутствующими им дерново-подзолами и дерновоподзолисто-глеевыми почвами: они занимают 3400 км², или $8,9 \%$ общей площади. В межгорных котловинах господствующее положение принадлежит серым метаморфическим почвам, дерново-подбурам с дерново-серыми почвами, а также псаммоземам гумусовым. В целом на долю этих почв приходится лишь 594 км².

Почвенный покров в поймах, устьях и дельтах рек представлен различными комплексами аллювиальных почв: темногумусовыми, темногумусовыми глеевыми, слоисто-аллювиальными, перегнойно-глеевыми, торфяно-глеевыми и др. На болотных массивах получили развитие торфяные эутрофные почвы, торфяно-глееземы, а также встречаются перегнойно-глеевые почвы, торфяно-глееземы и торфяно-криоземы. Приозерные территории преимущественно заняты темногумусовыми глеевыми и торфяными эутрофными почвами, а в местах впадения 
в озера или вытекания из них рек и речек - аллювиальными почвами. Засоленные почвы в исследованном регионе практически отсутствуют, т. к. встречаются только на очень малых по площади территориях, связанных с выходами различных минеральных источников. В целом на долю аллювиальных и болотных почв приходится 2405 км² (6,3 \% общей площади почв ЦЭЗ).

Благодарности: работа выполнена за счет средств государственного задания (№ госрегистрации темьл АAAA-A17-117011810038-7, АAAA-A17117041910169-4) и при финансовой поддержке РФФИ в рамках научного проекта № 18-45-030039.

\section{Литература}

1. Аненхонов О. А., Бойков Т. Г. Растительность Прибайкалья // Байкал: природа и люди: энциклопедический справочник. Улан-Удэ: ЭКОС; Изд-во БНЦ СО РАН, 2009. С. 295-301.

2. Атлас «Байкал». М.: РАН, 1993. 160 с.

3. Балсанова Л. Д., Гынинова А. Б., Цыбикдоржиев Ц. Ц., Гончиков Б.-М. Н., Шахматова Е. Ю. Генетические особенности почв бассейна озера Котокельское (Восточное Прибайкалье) // Почвоведение. 2014. № 7. С. 781-789.

4. Балсанова Л. Д., Найданов Б. Б., Мангатаев А. Ц. Элементы почвенной катены полуострова Святой Нос (Восточное Прибайкалье) // Вестник Северо-Восточного научного центра ДВО РАН. 2017. № 1. С. 44-51.

5. Белозерцева И. А., Владимиров И. Н., Убугунова В. И., Убугунов В. Л., Екимовская О. А., Бардаш А. В. Почвы водоохранной зоны озера Байкал и их использование // География и природные ресурсы. 2016. № 5. С. 62-71.

6. Белозерцева И. А., Убугунов Л. Л., Убугунова В. И., Доржготов Д., Гынинова А. Б., Убугунов В. Л., Сороковой А. А., Бадмаев Н. Б. Почвы Байкальского региона и прилегающих территорий // Успехи современного естествознания. 2018. № 8. С. 96-108.

7. Болонева М. В., Корсунов В. М. Почвы автоморфных ландшафтов придельтовой части реки Селенги. Улан-Удэ: Изд-во БНЦ СО РАН, 2008. 128 с.

8. Буфал В. В., Визенко О. С., Моложников В. Н. Микроклиматические особенности различных высотных поясов // Природные условия Северо-Восточного Прибайкалья. Новосибирск, 1976. С.110-143.

9. Горячкин С. В., Мергелов Н. С., Таргульян В. О. Генезис и география почв экстремальных условий: элементы теории и методические подходы // Почвоведение. 2019. № 1. C. 5-9.

10. Гынинова А. Б., Шоба С. А., Балсанова Л. Д., Гынинова Б. Д. Почвы дельты реки Селенги (генезис, география, геохимия). Улан-Удэ: Изд-во БНЦ СО РАН, 2012. 344 с.

11. Гынинова А. Б., Балсанова Л. Д. О сходстве дерновых серых лесных почв УстьСеленгинской впадины Влосточного Прибайкалья с палево-бурыми почвами Якутии // Наука и образование. 2009. № 3. С. 77-82.

12. Гынинова А. Б., Убугунов Л. Л., Куликов А. И., Гынинова Б. Д., Гончиков Б. Н., Бадмаев Н. Б., Сымпилова Д. П. Послепожарная эволюция лесных экосистем на песчаных террасах Юго-Восточного Прибайкалья // Сибирский экологический журнал. 2020. № 1. С. $13-25$.

13. Добровольский Г. В., Никитин Е. Д. Экология почв. Учение об экологических функциях почв. М.: Изд-во Моск. ун-та, 2012. 413 с. 
Л. Л. Убугунов, И. А. Белозериева, В. И. Убугунова, А. А. Сорокова. Эколого-географические закономерности распределения почв и почвенные ресурсы центральной экологической зоны...

14. Донская Т. В., Скляров Е. В., Гладкочуб Д. П., Мазукабзов А. М., Сальникова Е. Б., Ковач В. П., Яковлева С. З., Бережная Н. Г. Прибайкальский коллизионный метаморфический пояс // Доклады РАН. 2000. Т. 374 (7). С. 1075-1079.

15. Епова Н. А. Опыт дробного геоботанического районирования Хамар-Дабана (южная часть средней Сибири) // Проблемы геоботаники. М.; Л., 1960.Т.5. С. 47-64.

16. Классификация и диагностика почв России. Смоленск: Ойкумена, 2004. 342 с.

17. Козловский Ф. И., Горячкин С. В. Информационная структура почвенного покрова: поверхности раздела и внутренняя масса // Память почв: Почва как память биосферногеосферно-антропосферных взаимодействий. М.: Изд-во ЛКИ, 2008. С. 58-74.

18. Ладейщиков Н. П. Климатические ресурсы Байкала и его бассейна. Новосибирск, 1976. С. 272-305.

19. Линник Р. М. Серые лесные длительносезонномерзлотные почвы Бурятии: автореф. дис. ... канд. биол. наук. Новосибирск, 1978. 20 с.

20. Литвиновский Б. А., Занвилевич А. Н., Алакшин А. М., Подладчиков Ю. Ю. АнгароВитимский батолит — крупнейший гранитоидный плутон. Новосибирск: ОИГГМ СО PAH, 1993. $141 \mathrm{c.}$

21. Логачев Н. А. Саяно-Байкальское становое нагорье // Нагорья Прибайкалья и Забайкалья. История развития рельефа Сибири и Дальнего Востока. М., 1974. С. 16-162.

22. Мац В. Д. Байкальский рифт: плиоцен (миоцен) четвертичный эпизод или продукт длительного развития с позднего мела под воздействием различных тектонических факторов. Обзор представлений // Геодинамика и тектонофизика. 2015. Т. 6, № 6. С. 467-489.

23. Моложников В. Н. Растительные сообщества Прибайкалья. Новосибирск: Наука, 1986. $272 \mathrm{c}$.

24. Озеро Котокельское: природные условия, биота, экология / отв. ред. Н. М. Пронин, Л. Л. Убугунов. Улан-Удэ: Изд-во БНЦ СО РАН, 2013. 340 с.

25. Петрович П. И. Низинные торфяные почвы Бурятии (генезис и сельскохозяйственное использование). Улан-Удэ: Бурят. кн. изд-во, 1974. 139 с.

26. Плюснин В. М., Владимиров И. Н. Территориальное планирование Центральной экологической зоны Байкальской природной территории. Новосибирск: Гео, 2013. 411 с.

27. Полевой определитель почв России. М.: Почвенный ин-т им. В. В. Докучаева, 2008. $182 \mathrm{c}$.

28. Потапская Н. В., Куликова Н. Н., Тимошкин О. А., Зайцева Е. П., Непокрытых А. В., Мальник В. В. Оценка накопления отходов потребления в прибрежной зоне озера Байкал и дельте реки Селенги // География и природные ресурсы. 2016. № 1. С. 621-669.

29. Почвенный покров Бурятской АССР. Карта м-ба 1:1 000000 / ред. В. П. Мартынов, Ц. Х. Цыбжитов. М.: ГУГК, 1980. 4 л.

30. Резанов И. Н., Резанова В. П. Геоморфологическое строение побережья озера Байкал // Байкал. Природа и люди. Улан-Удэ: ЭКОС. Изд-во БНЦ СО РАН, 2009. С. 216-219.

31. Рыцк Е. Ю., Неймарк Л. А., Амелин Ю. В. Возраст и геодинамические обстановки формирования палеозойских гранитоидов северной части Байкальской складчатой области // Геотектоника. 1998. № 5. С. 46-50.

32. Салоп И. Г. Геология Байкальской горной области. М.: Недра, 1967. Т.2. 515 с.

33. Семиколенный А. А., Таргульян В. О. Почвоподобные тела автохемолитотрофных экосистем пещер хребта Кугитангтау (Восточный Туркменистан) // Почвоведение. 2010. № 6. C. 658-672.

34. Сутурин А. Н. Чебыкин Е. П., Мальник В. В., Ханаев И. В., Минаев А. В., Минаев В. В. Роль антропогенных факторов в развитии экологического стресса в литорали озера Байкал (акватория пос. Листвянка) // География и природные ресурсы. 2016. № 6. C. $43-54$. 
35. Тимошкин О. А., Бондаренко Н. А., Волкова Е. А., Томберг И. В., Вишняков С. В., Мальник В. В. Массовое развитие зеленых нитчатых водорослей родов Spirogyra и Stigeoclonium (Chlorophyta) в прибрежной зоне Южного Байкала // Гидробиологический журнал. 2014. Т. 50 (№ 5). С. 15-26.

36. Тюлина Л. Н. Влажный прибайкальский тип поясности растительности. Новосибирск: Наука, 1976. 319 с.

37. Убугунов Л. Л., Белозерцева И. А., Убугунова В. И., Сороковой А. А. Районирование почв бассейна озера Байкал: экологический подход // Природа Внутренней Азии. Nature of Inner Asia.2019a. № 2 (11). C. 40-59. DOI: 10.18101/2542-0623-2019-2-40-59.

38. Убугунов Л. Л., Белозерцева И. А., Убугунова В. И., Сороковой А. А. Экологическое районирование почв бассейна озера Байкал // Сибирский экологический журнал. 20196. № 6. С. 640-653.

39. Убугунов Л. Л., Борисова Н. Г., Аненхонов О. А., Балданова Д. Р., Базова Н. В., Убугунов В. Л. Возможные эколого-биологические последствия сооружения гидроэлектростанции на реке Селенге и ее притоках в Монголии // Известия Иркутского государственного университета. Сер. Биология. Экология. 2015. Т. 12. С. 58-72.

40. Убугунов Л. Л., Гынинова А. Б., Белозерцева И. А., Доржготов Д., Убугунова В. И., Сороковой А. А., Убугунов В. Л., Бадмаев Н. Б., Гончиков Б. Н. Географические закономерности распределения почв на водосборной территории оз. Байкал (к карте «Почвы бассейна оз. Байкал») // Природа Внутренней Азии. Nature of Inner Asia. 2018а. № 2(7). C. 7-26. DOI: $10.18101 / 2542-0623-2018-2-7-26$.

41. Убугунов Л. Л., Куликов А. И., Убугунов В. Л. Разнообразие, риски деградации и эколого-агрохимические технологии управления плодородием почв Внутренней Азии // Проблемы агрохимии экологии. 2016. № 2. С. 3-9.

42. Убугунов Л. Л., Убугунова В. И., Бадмаев Н. Б., Гынинова А. Б., Убугунов В. Л., Балсанова Л. Д. Почвы Бурятии: разнообразие, систематика и классификация // Вестник Бурятской гос. с.-х. академии им. В. Р. Филиппова. 2012. № 2. С. 45-52.

43. Убугунов Л. Л., Убугунова В. И., Белозерцева И. А., Гынинова А. Б., Сороковой А. А., Убугунов В. Л. Почвы бассейна оз. Байкал: итоги исследования за 1980-2017 гг. // География и природные ресурсы. 2018б. № 4. С. 76-87.

44. Убугунов Л. Л., Хутакова С. В., Убугунова В. И. Разнообразие и основы рационального использования гидроморфных почв Байкальского региона. Улан-Удэ: Изд-во БГСХА им. В. Р. Филиппова, 2013. 148 с.

45. Убугунова В. И. Генетические особенности основных типов горно-лесных почв хр. Хамар-Дабан (в пределах Байкальского государственного заповедника): автореф. дис. ... канд. биол. наук. Новосибирск, 1987. 16 с.

46. Цыбжитов Ц. Х., Убугунова В. И. Генезис и география таежных почв озера Байкал. Улан-Удэ: Бурят. кн. изд-во, 1992. 240 с.

47. Цыбжитов Ц. Х., Цыбжитов А. Ц. Почвы бассейна оз. Байкал. Генезис, география и классификация степных и лесостепных почв. Улан-Удэ: Изд-во БНЦ СО РАН, 2000. Т. 2. $165 \mathrm{c}$.

48. Цыбикдоржиев Ц. Ц., Бадмаев Н. Б. Факторы почвообразования бассейна реки Большая Сухая хребта Морского // Вестник БГУ. Биология. География. 2018. № 2. С. 57-68.

49. Цыбикдоржиев Ц. Ц., Гончиков Б.-М. Н., Балсанова Л. Д. Почвенный покров Баргузинского заповедника (на примере бассейна реки Давша) // «Природные резерваты гарант будущего»: материалы науч.-практ. конф. Улан-Удэ: Баргуз. ГПБЗ, 2017. С. 259-263.

50. Чепинога В. В., Протопопова М. В., Павличенко В. В. Выявление вероятных плейстоценовых микрорефугиумов на северном макросклоне хребта Хамар-Дабан (Южное Прибайкалье) // Сибирский экологический журнал. 2017. № 1. С. 44-50. 
51. Экологический атлас бассейна озера Байкал. Иркутск; Улан-Батор; Улан-Удэ: ИГСО PAH, 2015. $145 \mathrm{c}$.

52. Экологический атлас бассейна озера Байкал. Иркутск; Улан-Батор; Улан-Удэ: ИГСО PAH, 2015. $145 \mathrm{c}$.

53. Beyer L., Boelter M. (eds.) Geoecology of Antarctic Icefree Coastal Landscapes. SpringerVerlag Berlin Heidelberg, 2002. 427 p.

54. Bockheim J. G. The Soils of Antarctica. Springer, 2015. 322 p.

55. Mergelov N., Mueller C. W., Prater I., Shorkunov I., Dolgikh A., Zazovskaya E., Shishkov V., Krupskaya V., Abrosimov K., Cherkinsky A., Goryachkin S. Alteration of rocks by endolithic organisms is one of the pathways for the beginning of soils on Earth // Scientific Reports. 2018. V. 8. P. $1-15$.

\section{ECOLOGICAL AND GEOGRAPHICAL PATTERNS OF SOIL DISTRIBUTION AND SOIL RESOURCES OF THE CENTRAL ECOLOGICAL ZONE OF BAIKAL REGION (THE REPUBLIC OF BURYATIA)}

L. L. Ubugunov, I. A. Belozertseva, V. I. Ubugunova, A. A. Sorokovoy

Leonid L. Ubugunov

Dr. Sci. (Biol.), Prof., Institute of General and Experimental Biology SB RAS

6 Sakhyanovoy St., Ulan-Ude 670047, Russia

Philippov Buryat State Agricutural Academy

8 Pushkina St., Ulan-Ude 670000, Russia

1-ulze@mail.ru

\section{Irina A. Belozertseva}

Cand. Sci. (Geogr.),

Sochava Institute of Geography SB RAS,

1 Ulan-Batorskaya St., Irkutsk 664033, Russia

Irkutsk State University

5 Sukhe-Batora St., Irkutsk 664011, Russia

belozia@mail.ru

Vera I. Ubugunova

Dr. Sci. (Biol.), Prof.,

Institute of General and Experimental Biology SB RAS

6 Sakhyanovoy St., Ulan-Ude 670047, Russia

ubugunova57@mail.ru

Andrey A. Sorokovoy

Cand. Sci. (Geogr.),

Sochava Institute of Geography SB RAS,

1 Ulan-Batorskaya St., Irkutsk 664033, Russia

geomer@irigs.irk.ru

Abstract. Based on the results of many years' research and unified methodological and classification approaches we have studied the ecological and geographical patterns of soil distribution in the Central Ecological Zone (CEZ) of Baikal region (the Republic of Buryatia) 
and drawn a map of soil cover. At this stage of research, we have identified 38 soil types combined in 18 soil contours, determined their territorial distribution and estimated the soil resources area. The dominant effect of vertical zoning in spatial distribution of soils is associated with the mountainous topography of the studied region. It has been established that the soils of the mountain-tundra zone occupy a significant territory of $11,120 \mathrm{~km}^{2}$, or $29.3 \%$ of the total area. They are mainly represented by raw soils - lithozems and petrozems with associated soils and taiga gley cryogenic soil with boggy gley soil and boggy lithozems. We also have found membranous "soil-like" bodies. Most of the studied area (53.8\% of the total) is occupied by the soils of middle mountains, where parapodzols, burozems, sod-parapodzols, podzols, sodpodzols, raw-humus burozems etc. prevail. Dark humus, humous-dark humus, peat-cryozems, gleic peat-podburs etc. are met. A significant part of podburs in the soil cover of middle mountains is associated with the calc-alkaline Angara-Vitim batholiths preventing eluvial soil differentiation, and burozems - with the development of "warm" landscapes influenced by warming affect of the Lake Baikal waters. In low mountains podzols and gleic sod-podzols with accompanying sod-podzols and sod-podzolic-gley soils are dominant, they occupy $34 \mathrm{~km}^{2}$, or $8.9 \%$ of the total area. In intermountain basins, gray metamorphic soils, sod-podburs and sod-gray soils prevail, as well as humus psammozems, they occupy $594 \mathrm{~km}^{2}$ in total. Podzols and podburs with a slightly differentiated profile associated with the high prevalence of calc-alkaline dominate under the automorphic conditions in the northern and northeastern parts of the studied area. Sod-podzolic soils are common both for the plain and foothill zone of the Lake Baikal eastern coast. Dark humus and gray humus soils, which occupy a small part of the Central Ecological Zone (CEZ) are confined to the outcrops of marbles and their derivatives. Various complexes of alluvial soils are developed in the floodplain-delta landscapes and at river mouths, and peat eutrophic soils, peat-gley soils, etc. — on wetlands and bogs. Gleic dark humus and peat eutrophic soils are mainly developed on lakesides. In general, the share of bog and alluvial soils account for $2,405 \mathrm{~km}^{2}$ (6.3\% of the CEZ total area). Saline soils occupy small places: they are found only near mineral springs.

Keywords: soil; mapping; soil resources; Baikal region; the Central ecological zone; the Republic of Buryatia. 